\title{
CIVILIZAÇÃO E ALIENAÇÃO: DIÁLOGO COM FREUD E ADORNO
}

\section{Márcio Danelon}

\section{RESUMO}

O presente artigo tem por objetivo estabelecer um diálogo entre as reflexões de Adorno e Freud sobre a civilização. Procuraremos mostrar as críticas que Adorno construiu, basicamente em Dialética do Esclarecimento, sobre a racionalidade instrumental presente em nossa civilização tecnológica, denunciando o estado de alienação e insatisfação. Procuraremos, também, tomar a análise freudiana sobre a civilização, emergindo suas críticas sobre o caráter extremamente repressor da civilização e sua denúncia da infelicidade que esta acarreta ao homem.

PALAVRAS-CHAVE

Civilização; Ciência; Alienação; Felicidade

\section{CIVILIZATION AND ALIENATION: DIALOGUE WHIT ADORNO AND FREUD}

\begin{abstract}
The aim of this article is to establish a dialogue betwen the reflexion of Adorno and Freud about the civilization. We will try to show the cricticisms that Adorno constructed basically in Dialektik der Aufklaurüng about the instrumental rationality present in our tecnologic civilization denouncing the estate of alienation and insatisfaction. We wil also use Freud's analyses about the civization emerging his criticisms about the character extremely repressive of civilization and his denoucing of unhappiness which was caused to man.
\end{abstract}

KEYWORDS

Civilization; Science; Alienation; Happiness

(C) ETD - Educação Temática Digital, Campinas, v.8, n.esp., p.85-102, dez. 2006 - ISSN: 1676-2592. 


\section{INTRODUÇÃO}

O processo de fundação e constituição da civilização tornou-se objeto de reflexão acadêmica somente em meados da modernidade, mais especificamente, com a sociologia do século XIX. De fato, no mundo grego clássico, a pergunta fundante da filosofia é pela origem do cosmo e os elementos que o constituía. A vida coletiva era definida pela própria natureza humana. Quando Aristóteles define o homem como animal político, atribui a própria natureza humana seu modo de vida coletivo. Nesse caso, o homem se define enquanto tal por viver numa pólis, participando dela de forma efetiva, através do exercício da cidadania. Em A Política, Aristóteles, partindo dessa concepção antropológica, direciona sua reflexão para a finalidade da vida humana. Esta se realiza na vida social, na vida política. Emerge desse filósofo uma politologia, ou seja, um finalismo político. De fato, o homem, a família, a educação e a ética, entre outras, estão a serviço da cidade-estado. Entre os gregos, o estrangeiro não goza dos direitos políticos, além de ser tomado, em muitas situações, como paria, como desprezível.

A intrincada relação entre o social e o individual não emergia como problema na filosofia clássica, nem mesmo na medieval. O problema da separação entre público e privado e a emergência do espaço público constituem-se numa invenção moderna. É na modernidade que se torna problemática de reflexão o indivíduo inserido num espaço público. Erasmo de Rotterdam, por exemplo, em A Civilidade Pueril expressa sua preocupação na formação das crianças para viverem no espaço público de forma mais civilizada possível. Esta obra, que se constitui também num manual de etiqueta, a formação da criança responde aos valores expressos no meio social, de forma que sua vestimenta, seu comportamento, modos de falar e de se dirigir para o outro, seu comportamento nas refeições e em outros espaços sociais devem respeitar um código de conduta rígido de forma que permita a convivência coletiva. De fato, nesta obra, Erasmo determina a superioridade do espaço público e suas normas de organização sobre o indivíduo.

O final da modernidade, com pensadores como Kierkegaard, Schopernhauer e Nietzsche, não somente fazem um diagnóstico da civilização moderna, mas passam a explorar um tema particularmente profícuo para a psicologia que estava se constituindo e para a psicanálise, em vias de ser inventada por Freud: a temática da existência na tensão entre a coletividade e a individualidade, ou seja, a saúde, a doença, bem como a dimensão espiritual, e a volitiva estão sujeitas as vicissitudes da vida coletiva. Nesse caso, a saúde e a doença não se limitam tão 
somente ao orgânico, mas estão intrinsecamente ligadas ao modo de vida socio/gregário. É esta dinâmica entre a civilização e o indivíduo que se constitui como mote deste trabalho. Quero explorar, neste caso, como o processo civilizatório produziu um sujeito alienado e infeliz a partir das reflexões de Adorno \& Horkheimer (1985) na obra Dialética do Esclarecimento. Desse modo, pretendo demonstrar que, para esses pensadores da dialética negativa, o processo de emancipação da razão esclarecida de toda subjugação à natureza produziu avanços fantásticos do ponto de vista da construção de um modo confortável e seguro de existência, mas, essa mesma razão esclarecida produziu, também, um sujeito alienado, omisso, ressentido e sem singularidade. Num segundo momento, partirei da análise da obra $O$ mal-estar na civilização, publicada em 1930 por Sigmund Freud (1990) para demonstrar o desencanto com o processo civilizatório e suas conseqüências para o funcionamento do aparelho psíquico. O objetivo desse artigo é sustentar que a civilização produziu um sujeito alienado e doente.

\section{ESCLARECIMENTO E CIVILIZAÇÃO: A PRODUÇÃO DO HOMEM ALIENADO}

Na obra Dialética do Esclarecimento, publicada em Amsterdã em 1947, Adorno e Horkheimer resgatam o conceito de esclarecimento. Este conceito é remetido pelos autores ao processo de desencantamento do mundo e de dominação dos homens. Kant, no século XVIII, escreveu um texto célebre cujo título era Resposta à pergunta: o que é Esclarecimento. Nesse texto, Kant define o esclarecimento como o processo emancipatório do homem frente à ignorância, isto é, graças ao poder esclarecedor da razão, os homens puderam se libertar do medo que os mistérios da natureza desconhecida neles infligia. Assim, a ciência, que é produto da razão esclarecida, é também o princípio de explicação do universo agora subjugado à razão. Outro interlocutor dos autores é Hegel. Com o propósito de tensionar a dialética hegeliana, os filósofos de Frankfourt, procuraram demonstrar o caráter negativo do método. Ora, se em Hegel a dialética se resolve numa síntese, portanto o círculo se fecha, a dialética negativa encerra-se na tensão da negatividade.

Na Dialética do Esclarecimento, o conceito de esclarecimento aparece impregnado de um sentido, não somente positivo como em Kant, mas, também, negativo, na medida em que o esclarecimento, que investiu os homens do poder de dominar a natureza, trouxe, por outro lado, o processo de alienação do homem, não mais frente a uma natureza hostil, mas sim a um sistema 
econômico/social extremamente violento e inumano. Assim, o esclarecimento adquire a significação de desencantamento do mundo, e o produto do esclarecimento - uma sociedade desenvolvida - adquire o sentido de dominação dos homens pelo sistema econômico/social. Dessa forma, faz sentido o título do texto adorniano: Dialética do Esclarecimento. Admitindo que o termo esclarecimento é dialético na medida em que, ao mesmo tempo em que reveste os homens do poder de dominadores do mundo, reveste-os, também, com o manto de seres alienados e submissos, que perderam frente ao sistema aquilo que tinham de mais valioso: a sua individualidade. Dessa forma, o processo de esclarecimento do homem traz em seu bojo o processo de diluição do homem individual numa massa sem identidade própria.

O esclarecimento, produto de uma razão que se libertou do dogmatismo religioso e natural, que se libertou da submissão para tomar as rédeas da existência humana produziu, no decorrer dos séculos, avanços estrondosos na subjugação da natureza ao eu racional. Graças ao esclarecimento, a natureza deixou de produzir medo e tornou-se serva dos homens na medida em que estes, ao subjugá-la, constroem os meios necessários para o desenvolvimento de todo o aparato cultural. Nessa perspectiva, foi a partir de uma racionalidade livre dos dogmas que se produziu a grande explosão científica dos últimos séculos.

O conceito de esclarecimento com que Kant está dialogando é depositário de um ideal de racionalidade oriunda da filosofia de Descartes entre os séculos XVI e XVII, ou seja, o esclarecimento que trouxe autonomia para os homens frente a natureza e frente às superstições religiosas, é produto de um ideal de razão capaz de produzir, autonomamente, conhecimento e explicação sobre a realidade.

Esse valor dado à razão foi desenvolvido por Descartes, principalmente em Discurso do Método, publicado em 1637, e nas Meditações Metafísicas, publicada em 1641. Assim, situa-se no crepúsculo do obscurantismo e dogmatismo que marcou o período da Idade Média, época em que a racionalidade humana se encontrava em estado de profunda submissão ao poder revelador de Deus. Assim, nas “trevas” do medievo, o conhecimento não era produzido pela razão humana, mas revelado a essa razão pela divindade. Descartes, também, encontra-se no limiar da Idade Moderna, período em que se creditou ao homem condições para produzir conhecimento. Nessa perspectiva, Descartes foi, talvez, um dos primeiros a descolar o eixo da racionalidade humana que se dirigia, de forma efetiva, para Deus, voltando-a sobre a natureza e o próprio homem. Nas Meditações Metafísicas, Descartes questiona-se sobre o que é o homem, e, em suas reflexões, 
descreve atributos para o ser humano, chegando ao principal desses atributos: o pensamento. Cito Descartes:

\begin{abstract}
Um outro é pensar, e verifico aqui que o pensamento é um atributo que me pertence; somente ele não pode ser separado de mim. Eu sou, eu existo: isto é certo; mas por quanto tempo? Durante todo o tempo em que eu penso; pois talvez poderia acontecer que, se eu parasse de pensar, ao mesmo tempo pararia de ser ou de existir. Nada admito agora que não seja obrigatoriamente verdadeiro: nada sou, então, a não ser uma coisa que pensa (...). (DESCARTES, 1987a, ps. 260-261).
\end{abstract}

Podemos perceber, neste texto, que a existência de algo, inclusive do próprio homem, é produto de um pensamento. Em outras palavras, é a razão, através do pensamento, que atribui sentido ao mundo oral. Sem o homem pensante, o mundo não teria sentido. ${ }^{1}$ No Discurso do Método, Descartes (1987, ps. 43-52) propõem quatro etapas que compõem o método para o conhecimento: evidência, análise, síntese e revisão. Este método cartesiano irá marcar profundamente todo o desenvolvimento das ciências naturais no século XVIII. Desta feita é que Descartes vincula uma racionalidade que toma o real como objeto de estudo e produz conhecimento. Como conseqüência, a razão passa a ter valor importante num mundo a ser construído pelo homem. É esse valor do conhecimento que marca a cisão cartesiana entre o crepúsculo das trevas medievais para o limiar iluminista da modernidade.

Esta aurora de uma nova civilização era um sentimento alimentado pelo próprio contexto histórico do século XVII. As novas terras “achadas” pelas grandes navegações, que deveriam ser povoadas e desenvolvidas, e a possibilidade trazida pelas descobertas de Galileu de um universo aberto e, portanto, a ser conhecido pela razão humana, encheram de desafios o poder da racionalidade humana em construir uma civilização que primasse pelo desenvolvimento econômico, social, político e científico. É nesse sentido que havia uma nova cidade, um novo Estado, um novo mundo a ser construído pela racionalidade humana.

Para a filosofia do século XVII, a ciência deveria ser o meio pelo qual essa deveria ser fundada essa nova civilização. Foram muitas as invenções do início da Idade Moderna, cujo objetivo maior era proporcionar uma forma de vida mais confortável nas cidades que se multiplicavam. Assim, o ideal cientificista deveria produzir tecnologia para uma nova forma de

\footnotetext{
${ }^{1}$ Conforme a passagem a seguir: "Muitos consideram que a filosofia moderna tem início com as perguntas de Descartes sobre se podemos ou não ter a confiança de que nossas mentes sabem o que está se passando lá fora. Passa até na cabeça das crianças perguntar-se, quando uma árvore cai no meio de uma floresta onde não há ninguém para ouvir, se isso realmente faz algum barulho" (ELLIOTT, 1997, p. 270).
}

(c) ETD - Educação Temática Digital, Campinas, v.8, n.esp., p.85-102, dez. 2006 - ISSN: 1676-2592. 
vida até então desconhecida: a vida em grandes cidades. As ciências se transformaram no novo demiurgo transformador da natureza e construtor da realidade humana e que culminou no valor exacerbado dado à ciência pelo positivismo. Dessa forma, no século XIX, a ciência foi a garantidora de uma civilização que promovesse o desenvolvimento tecnológico, social, político e econômico. Em última instância, a nossa atual civilização, marcada pela ciência e pela tecnologia, é produto dessa aposta na razão humana advinda deste Descartes.

O desenvolvimento científico desde o século XVII e, como produto, a nossa cultura, foi resultante de um uso determinado da nossa razão, ou seja, a nossa cultura extremamente tecnológica e industrial é resultado da razão instrumentalizada, isto é, uma razão que deixa de ser contemplativa e passa a ser operativa da natureza. A idéia da passagem de uma razão contemplativa da natureza para operativa, marca, decisivamente, o limiar da Idade Moderna, no sentido de que durante toda a Idade Média o homem, a natureza e o cosmo eram objetos de contemplação e admiração do homem uma vez que eram reflexos da perfeição divina e manifestação concreta da ordem de Deus. Portanto, não poderiam ser transformados pela razão humana. Na Idade Moderna, ao contrário, a razão passa a tomar o homem², a natureza e o cosmo ${ }^{3}$ como objetos de estudo. Assim, o mundo, além do próprio homem, transforma-se num meio, num instrumento com que o homem, através da razão operativa, transforma, conforme com suas necessidades materiais e/ou econômicas. O produto dessa razão instrumentalizada é o desencantamento do mundo, ou seja, o universo, na modernidade, perdeu seu encanto para se transformar em objeto de manipulação do homem. É assim que a ciência, nascida da razão instrumentalizada, transforma rios em depósito de lixo, árvores seculares em móveis de luxo, pele de animais em casacos, bolsas e sapatos. Nesse sentido, o valor do conhecimento que a razão produz é equivalente a quantidade de bens produzidos por ela. Assim, a razão instrumentalizada

\footnotetext{
${ }^{2}$ Michel Foucault, em As palavras e as coisas (1990), irá apontar exatamente este problema derivado da inauguração cartesiana da consciência humana na medida em que, a partir da consciência cartesiana, o homem passa a ser objeto de estudo de si mesmo. No capítulo IX desta obra, "O homem e seus duplos”, Foucault vai problematizar esta crise do sujeito que faz de si mesmo, que transforma a si mesmo em objeto amorfo do conhecimento, ou seja, é uma consciência conhecendo a própria consciência. Na quinta parte do Discurso do Método, Descartes (1987) define o homem como objeto de estudo ao fazer toda uma elaboração sobre o funcionamento do aparelhe circulatório do homem.

${ }^{3} \mathrm{O}$ ideal de abarcar a natureza como objeto de estudo remonta à filosofia empirista, que parte do pressuposto de que somente podemos conhecer os fenômenos passíveis de experiência empírica. No século XVI Francis Bacon foi o primeiro empirista a voltar os olhos sobre a natureza como sendo o único objeto do conhecimento humano. É nesta época que a natureza perde sua áurea de intocabilidade.
}

(c) ETD - Educação Temática Digital, Campinas, v.8, n.esp., p.85-102, dez. 2006 - ISSN: 1676-2592. 
deve estar a serviço do processo de desenvolvimento de uma cultura que prima pela ciência e pela tecnologia.

É bem verdade que essa razão instrumentalizada foi, talvez, a maior responsável pelo grau de desenvolvimento de que nossa civilização desfruta. Nessa perspectiva, vivemos numa sociedade que possibilita aos homens, ou a uma parte deles, condições tecnológicas que facilitam a vida em coletividade, tais como: facilidade na comunicação, rapidez no transporte, maior longevidade de vida, produção cultural sem nenhum precedente na história. Graças a racionalidade instrumentalizada, a nossa civilização pôde proporcionar aos homens facilidades na satisfação de suas necessidades básicas de existência e, também, nos caprichos de consumo despertados pela cultura. Vivemos num mundo que prima, para uma parte da população, é evidente, pelo conforto. A razão, através da ciência e da tecnologia, produziu, destarte, ganhos fantásticos na facilidade em se viver e em que quase nunca pensamos, tais como: luz elétrica, água encanada, esgoto, facilidade na obtenção de alimentos, facilidade na comunicação e informação. Realmente, a razão esclarecida possibilitou aos homens um bem que tornou a vida humana muito mais fácil de ser vivida.

Porém, à luz de Adorno e Freud, podemos perguntar: qual foi o preço que pagamos por esse tipo de vida que ora desfrutamos? Quais exigências a civilização nos atribuiu como troca pelo conforto que temos? Na ótica desses dois pensadores, pagamos preços altíssimos pela organização da nossa civilização: a escravidão diária no trabalho, a alienação no trabalho, no lazer, no consumo, na repressão dos desejos do homem, na ausência de liberdade, na diluição do homem numa massa sem rosto ou identidade. É assim que, como afirmamos acima, na ótica adorniana, o esclarecimento é dialético, isto é, juntamente com um bem produz um mal, e na medida em que transforma os homens em seres alienados pelo próprio sistema, torna-os submissos e diluídos na massa. É nesse sentido que o esclarecimento revela seu teor de irracionalidade, pois, que racionalidade existe numa civilização que constrói campo de extermínio ou que realiza limpeza étnica? Que racionalidade existe num mundo em que, de um lado jogam-se alimentos no lixo, enquanto do outro lado milhares de pessoas morrem de fome? Que racionalidade existe num mundo em que pessoas fazem de pessoas escudos para se proteger, ou usam-nas como objetos em atos de violência regados a sadismo sexual? Que racionalidade existe num mundo em que o simples apertar de uma tecla num computador de um banco pode levar um país inteiro à ruína e milhares de pessoas à miséria? Que racionalidade existe num 
mundo em que é roubado de milhares de pessoas, já ao nascer, o sonho de uma perspectiva de vida melhor? Para Adorno, quando a civilização chega neste estado perde totalmente qualquer resquício de um ideal humanista ${ }^{4}$. Tal é a dialética adorniana da razão esclarecida: ela produz conforto e miséria, saúde e doença, riqueza e pobreza, vida e morte. É essa a ambigüidade da nossa civilização "racional”. Dessa forma, a nossa civilização desenvolvida sustenta-se em bases racionais que, por sua vez, produzem, também, estados de profunda barbárie.

É justamente esse caráter dúbio da racionalidade que Adorno e Horkheimer denunciam com o texto A Dialética do Esclarecimento, e é justamente este argumento que pretendemos recortar e relacionar com Freud, qual seja, o de que a civilização, produto de uma racionalidade instrumentalizada, remeteu os homens ao tártaro da infelicidade e da frustração. Se, para Adorno, a civilização produziu o mal-estar da alienação e da subjugação dos homens ao sistema, e isto fica claro nesta citação:

O aumento da produtividade econômica, que por um lado produz as condições para um mundo mais justo, confere por outro lado ao aparelho técnico e aos grupos sociais que o controlam uma superioridade imensa sobre o resto da população. O indivíduo se vê completamente anulado em face dos poderes econômicos. Ao mesmo tempo estes elevam o poder da sociedade sobre a natureza a um nível jamais imaginado. Desaparecendo diante do aparelho a que serve, o indivíduo se vê, ao mesmo tempo, melhor do que nunca provido por ele. Numa situação injusta, a impotência e a dirigibilidade da massa aumentam com a quantidade de bens a ela destinados. (ADORNO \& HORKHEIMER, 1985, p. 14)

No "Prefácio" de A Dialética do Esclarecimento, os autores colocam a questão norteadora da reflexão: "O que nos propuséramos era, de fato, nada menos do que descobrir por que a humanidade, em vez de entrar num estado verdadeiramente humano, está afundando numa espécie de barbárie” (ADORNO \& HORKHEIMER, 1985, p.11). Isso constitui no tema norteador da reflexão de Adorno e Horkheimer: o uso que o homem faz de sua razão possibilitou grandes desenvolvimentos tecnológicos e uma estrutura de organização social jamais vista. A ciência, aliada à tecnologia, possibilitou conforto à vida humana, porém, tal é o paradoxo

\footnotetext{
${ }^{4}$ Claud Gilbert Dubois em O imaginário da Renascença, especificamente num capítulo intitulado "Anthropos: a construção do ego", define humanismo da seguinte forma: "O humanismo é a descoberta do homem como sujeito, não mais como essência ou objeto. Nem rival de Deus, nem simples 'mosca entre as mãos de deuses cruéis'. O homem nada mais que humano, porém cada vez mais humano - esse é o objetivo do humanismo” (DUBOIS, 1995, p. 198). É esse valor dado ao humano pelo movimento humanista que, em nossa civilização tecno/científica, se perdeu. Assim, a ciência faz do homem um fantoche em que ela controla nossos gostos, aquilo que consumismo, as formas de lazer, a maneira de se vestir. Se antes do renascimento o homem é um joguete dos deuses, e, portanto sem humanidade, hoje o homem é um joguete da ciência, perdendo, também, o sentido de ser um ser humano.
}

(C) ETD - Educação Temática Digital, Campinas, v.8, n.esp., p.85-102, dez. 2006 - ISSN: 1676-2592. 
apontado pelos autores: essa mesma ciência e tecnologia que produziram maravilhas produziram, também, a própria ruína do homem, na medida em que o aprisionaram e o escravizaram na obrigatoriedade de um trabalho rotineiro, sem reflexão e alienado; em uma forma de lazer banal e em uma mídia com programas que elevam a mediocridade da humanidade. Nesse sentido, a questão levantada é sobre o próprio sentido de uma ciência responsável pelo bem, mas, responsável também pelo mal do homem: “(...) no colapso atual da civilização burguesa, o que se torna problemático não é apenas a atividade, mas o sentido da ciência” (ADORNO \& HORKHEIMER, 1985, p. 11). A questão de fundo nesta crítica à civilização - que baseia o esclarecimento no desenvolvimento exacerbado da ciência - constitui-se no próprio valor da ciência: qual o valor de uma ciência que produz máquinas fantásticas ao nosso cotidiano, se produz, também, o mal-estar, as doenças ${ }^{5}$ que o homem somatiza por viver uma vida alienada ${ }^{6} \mathrm{e}$ sem sentido? Assim, a mesma razão que prolonga ou diminui o sofrimento do homem aumenta, na mesma proporção, a barbárie do nosso mundo. Ainda no "Prefácio" lemos:

A aporia com que defrontamos em nosso trabalho revela-se assim como o primeiro objeto a investigar: a autodestruição do esclarecimento. Não alimentamos dúvida nenhuma (...) de que a liberdade na sociedade é inseparável do pensamento esclarecedor. Contudo, acreditamos ter reconhecido com a mesma clareza que o próprio conceito desse pensamento (...) contém o germe para a regressão que hoje tem lugar por toda parte. (ADORNO \& HORKHEIMER, p. 13)

E mais adiante, no capítulo $O$ Conceito de Esclarecimento, encontramos:

No sentido mais amplo do progresso do pensamento, o esclarecimento tem perseguido sempre o objetivo de livrar os homens do medo e de investi-los na posição de senhores. Mas a terra totalmente esclarecida resplandece sob o signo de uma calamidade brutal. (ADORNO \& HORKHEIMER, p. 19).

Continuando com Adorno, a terra resplandece sob o signo da crise de um projeto de construção de uma civilização tecno/industrial que fracassou, e fracassou porque não garantiu,

\footnotetext{
${ }^{5}$ É interessante observarmos este aspecto da doença mental do homem quanto ao nascimento da psicologia como a ciência humana encarregada de curar esse tipo de doença. É curioso notarmos que, oficialmente, a psicologia enquanto ciência nasceu no século XIX, especificamente em 1873, com os experimentos de Wundt, exatamente num período de grande efervescência científica na esteira ideológica do positivismo de Comte. O interessante é notar que esse mesmo século XIX marca o advento de uma vida urbana nas grandes cidades e de uma jornada de trabalho estonteante nas fábricas. Assim, podemos associar o surgimento desse modelo de vida, desenvolvido pela tecno/ciência com doenças psicológicas tais como: depressão, angústia, solidão, neurose, fobia. A psicologia surgiu, exatamente, como uma ciência que iria cuidar dessas novas doenças modernas, doenças essas cuja origem estaria num modelo de vida emanado da ciência instrumentalizada. Em última instância, a sociedade tecno/científica com seu ritmo de vida alucinante criou doenças nos homens e criou, também, uma forma de tratá-las.

${ }^{6}$ Erich Fromm (1983), em Psicanálise da sociedade contemporânea, desenvolve bem o conceito de alienação, associando-o às doenças de ordem psicológica, apontando, exatamente, o contexto da nossa civilização científica e industrial como a causa geradora dessa alienação e mal-estar.
}

(C) ETD - Educação Temática Digital, Campinas, v.8, n.esp., p.85-102, dez. 2006 - ISSN: 1676-2592. 
sequer, uma qualidade de vida material para todas as pessoas e, também, para aumentar a tragicidade da existência, instaurou no homem o mal-estar originado da alienação, da diluição da individualidade numa massa sem identidade e sem rosto. Assim, o desenvolvimento da civilização trouxe o progresso tecnológico o qual, para Adorno e Horkheimer, trouxe também a regressão do homem ao inumano.

A Dialética do Esclarecimento assume o caráter de uma obra que denuncia o aspecto negativo dessa racionalidade instrumentalizada, pois mostra que esta razão remeteu o ser humano a uma forma de vida inumana. Desse modo, a razão esclarecedora, ao fundar nossa civilização tecnológica e industrial, inaugura junto dela um tipo de homem diluído na massa; na civilização, o homem perde sua própria identidade, seu próprio eu. Cito:

O homem recebe seu eu como algo pertencente a cada um, diferente de todos os outros, para que ele possa com tanto maior segurança se tornar igual. Mas, como isso nunca se concretizou, o esclarecimento sempre simpatizou, mesmo durante o período do liberalismo, com a coerção social. A unidade da coletividade manipulada consiste na negação de cada indivíduo; seria digna de escárnio a sociedade que conseguisse transformar os homens em indivíduos. (ADORNO \& HORKHEIMER, 1985, p. 27).

O argumento mostra a denúncia que os autores fizeram ao processo civilizatório: o objetivo da sociedade não é garantir a individualidade, pois os desejos, paixões e prazeres individuais subvertem a ordem social. Nesse mesmo sentido, o objetivo da sociedade é a coesão social, e não o bem-estar do indivíduo. Ao contrário, o bem-estar da pessoa é a posteriori à coesão social, em outras palavras, é a paz social, a harmonia e o progresso social são primordiais e deverão garantir o bem-estar dos homens.

O processo de desenvolvimento civilizatório, cujo maior objetivo era proteger e perpetuar a espécie humana através da união dos homens numa coletividade trouxe em seu bojo a alienação dos homens em relação à própria civilização. A vida gregária que permitiu a propagação da espécie permitiu também, uma grande parcela de insatisfação aos homens na medida em que o indivíduo perde as rédeas de sua própria existência; na civilização, os homens se transformaram em seres desprovidos de rostos; em submissa massa de cordeiros que segue o pastor; em simples tijolos num muro, enfim, os homens se transformaram em simples objetos de manipulação:

Agora que uma parte mínima do tempo de trabalho à disposição dos donos da sociedade é suficiente para assegurar a subsistência daqueles que ainda se fazem necessários para o manejo das máquinas, o resto supérfluo, a massa imensa da população, é adestrada como uma guarda suplementar do sistema, a serviço dos seus planos grandiosos para o

(C) ETD - Educação Temática Digital, Campinas, v.8, n.esp., p.85-102, dez. 2006 - ISSN: 1676-2592. 
presente e o futuro. Eles são sustentados como um exército de desempregados. Rebaixados ao nível de simples objetos do sistema administrativo, que pré-forma todos os setores da vida moderna, inclusive a linguagem e a percepção, sua degradação reflete para eles a necessidade objetiva contra a qual se crêem impotentes (ADORNO \& HORKHEIMER, 1985, p. 49).

A segurança, o bem-estar material, a longevidade maior proporcionada aos homens pela vida na civilização foram alcançadas graças a um preço altíssimo pago pelo homem: sua felicidade. Isto é, a vida na sociedade somente é possível no momento em que os homens abrem mão do seu desejo individualizado, de sua decisão individual e dilui-se no coletivo, assim, o desejo transforma-se na civilização no dever. É nessa perspectiva que a civilização se funda: na negação e repressão dos desejos e aspirações individuais. Desse modo, o homem passa a ser um objeto de manipulação do sistema, pois, na perpetuação da civilização é necessário extrair dos homens o poder de escolha daquilo que lhes dá prazer. Essa necessidade de subtrair do homem o poder de nominar o objeto do prazer é fundamental para a constituição da civilização. Paralelo a subtração, a civilização impõe aos homens, através da moral, das leis jurídicas e da religião, as formas corretas para o “desfrute do prazer”, ou seja, de uma forma de prazer que tenha a aceitação social e não cause escândalo aos olhos do outro.

No projeto da civilização não cabe aos homens ser felizes, pois a felicidade é individual e contingente e a organização da sociedade não pode depender da satisfação do indivíduo. Nesse sentido, a vida na civilização é formada por homens ressentidos, resignados e frustrados, que cotidianamente reprimem seus desejos que iriam lhes proporcionar prazer, para realizar as exigências morais, religiosas e econômicas necessárias à manutenção da civilização. Cito: “A humanidade teve que se submeter a terríveis provações até que se formasse o eu, o caráter idêntico, determinado e viril do homem, e toda infância ainda é de certa forma a repetição disso” (ADORNO \& HORKHEIMER, 1985, p. 44). A infância aparece como a representação desse processo de negação dos desejos necessário à integração na sociedade, uma vez que na infância é que se vão introjetando os “nãos” imprescindíveis para a constituição da civilização.

Nessa dimensão, o projeto civilizatório pelo qual todos os homens passam, é marcado notadamente pela repressão das individualidades em função da organização social. Assim, a necessidade do trabalho produtivo extremamente rotineiro, a subjugação aos valores morais e 
religiosos, a hierarquia social, marcam a existência humana com o ferro da frustração. Cito Adorno:

\begin{abstract}
O medo de perder o eu e o de suprimir com o eu o limite entre si mesmo e a outra vida, o temor da morte e da destruição, está irmanado a uma promessa de felicidade, que ameaça a cada instante a civilização. O caminho da civilização era o da obediência e do trabalho, sobre a qual a satisfação não brilha senão como mera aparência, como beleza destituída de poder. (ADORNO, HORKHEIMER, 1985, pp. 44,45)
\end{abstract}

Cabe aqui destacar que, na ótica de Adorno e Horkheimer, a felicidade ameaça a nossa civilização, no sentido de que ser feliz implica em subverter e aniquilar a ordem social do trabalho, da religião e da moral. Assim, ser feliz remete para a liberdade do agir fiel àquilo que mais dá prazer aos homens. Dessa forma, é tarefa imprescindível da civilização abolir essa felicidade ${ }^{7}$ subvertedora da ordem.

Nessa interpretação, a situação do homem civilizado é sui generis, uma vez que o grande projeto da razão esclarecida era de dotar os homens do poder de dominadores da natureza, e, a partir disso, fundar uma civilização cujo objetivo maior era a garantia da satisfação e do bemestar do homem. Dessa forma, a civilização nasceu com esse propósito de garantir aos homens a felicidade. Da proteção dos primitivos à dominação total da natureza pelos modernos, o processo civilizatório sempre almejou a felicidade do homem. Porém, o processo civilizatório trouxe, também, em seu bojo, a alienação do homem, a insatisfação consigo mesmo e com o mundo, a ausência de perspectivas de realização dos desejos. Ou seja, a mecanização e automação do ser humano pela sociedade moderna, trouxeram uma grande parcela de insatisfação aos homens, haja vista o grande consumo de antidepressivos em nossa sociedade. Em função do grau de alienação e insatisfação do homem moderno, a civilização criou o protótipo de ser humano moderno, o prozac-mem. Em suma, a vida em civilização produziu homens submissos, malogrados; produziu homens ressentidos e doentes, que apenas sobrevivem ao gosto dos deuses do mercado e da política. Da ilusão de uma humanidade, restou aos homens a realidade de uma inumanidade: “A maldição do progresso irrefreável é a irrefreável regressão”. (ADORNO \& HORKHEIMER, 1985, p. 46).

\footnotetext{
${ }^{7}$ Num texto contemporâneo a Dialética do Esclarecimento, intitulado Dialética negativa (1975), Adorno, no capítulo "Meditações sobre a Metafísica", faz uma reflexão interessante sobre o problema da felicidade numa parte deste capítulo que tem o curioso título de "A felicidade e a espera inútil.
}

(C) ETD - Educação Temática Digital, Campinas, v.8, n.esp., p.85-102, dez. 2006 - ISSN: 1676-2592. 


\section{CIVILIZAÇÃO E MAL-ESTAR: A PRODUÇÃO DO HOMEM INFELIZ}

Na obra O Mal-estar na Civilização, Freud (1990) denunciou o drama vivido pelo homem na civilização. Este livro de Freud é considerado pela crítica como a expressão do pessimismo do fundador da psicanálise em relação ao processo civilizatório. Publicado em 1930, no tempo intermediário entre a Primeira e a Segunda Guerra Mundial, o diagnóstico de Freud revelou a “insanidade” do homem moderno: seu drama existencial é resultado do conflito entre as exigências pulsionais e as leis que normatizam as relações dos indivíduos entre si. A perene interdição do desejo produz sujeitos “doentes”, incomodados com o mundo e com a própria vida.

O processo civilizatório produziu um mundo organizado em valores e num aparato burocrático que determina nosso mundo econômico e social. Numa relação dialética com a civilização, o homem é produto e produtor desse mundo todo organizado em regras, costumes e leis que nos permite viver cada dia. Essa mesma civilização que nós produzimos para tornar possível a perpetuação de nossa espécie é produtora, por outro lado, desse sujeito doente, infeliz, fracionado em seu desejo e condenado a se deparar constantemente com a falta.

é impossível desprezar o ponto até o qual a civilização é construída sobre uma renúncia à pulsão, o quanto ela pressupõe exatamente a não-satisfação (pela opressão, repressão ou algum outro meio?) de pulsões poderosas. Essa 'frustração cultural domina o grande campo dos relacionamentos sociais entre os seres humanos. (FREUD, 1990, p. 118)

Encontramos nessa obra de Freud a mesma problemática da tensão dialética do processo civilizatório tal como demonstrado em Adorno e Horkheimer. Para o fundador da psicanálise, a civilização produziu ganhos importantes para a vida humana. O uso operativo da razão trouxe segurança e conforto para nossas casas, trouxe maior longevidade para a vida, as doenças são combatidas de forma eficaz, as distâncias foram diminuídas. Sem dúvida, o homem moderno construiu, infelizmente não para todos, um mundo melhor para se viver. Mas, ao produzir essa civilização o homem pagou o preço vendendo sua alma ao “diabo”: a felicidade não faz parte do projeto civilizatório. Assim, também em Freud, o desenvolvimento civilizatório é paralelo ao processo de repressão e insatisfação dos homens.

(C) ETD - Educação Temática Digital, Campinas, v.8, n.esp., p.85-102, dez. 2006 - ISSN: 1676-2592. 


\section{Grupo de Estudos e Pesquisa Diferenças e Subjetividades em Educação Grupo de Leitura de Freud}

Durante as últimas gerações, a humanidade efetuou um progresso extraordinário nas ciências naturais e em sua aplicação técnica, estabelecendo seu controle sobre a natureza de uma maneira jamais imaginada (...) Contudo, parecem ter observado que o poder recentemente adquirido sobre o espaço e o tempo, a subjugação das forças da natureza (...) não aumentou a quantidade de satisfação prazerosa que poderiam esperar da vida e não os tornou mais felizes. (FREUD, 1990, p. 107)

Não há, de fato, um paraíso perdido, não há um telos que deve ser buscado, pois homem e civilização se constituíram mutuamente. Não há homem sem civilização como o inverso também é verdadeiro. Portanto, não há superação dessa tensão: a neurose é constituidora do homem e a distinção entre saúde e doença encontra-se, então, na medida em que uma neurose deu certo e de outra neurose que não deu certo.

A produção de homens “doentes” pela civilização se efetiva através da tessitura dos valores, dos conceitos produzidos pela linguagem. A “doença”, essa talvez seja a grande descoberta freudiana, é da ordem da linguagem. Essa linguagem que se tornou problema constituindo da dimensão humana no século XIX. ${ }^{8}$ Nietzsche compreendeu, com rigor, a constituição humana pela linguagem e, de forma inovadora, situou a produção do ressentimento e do ideal ascético, as doenças do homem moderno, na esfera dos valores e da moral, da linguagem, portanto. Nessa mesma linha, Freud sistematizou a relação da “doença” com a linguagem ao estruturar o funcionamento do aparelho psíquico. Nessa perspectiva, na obra O Ego e o Id (1990a), Freud efetivou sua caracterização do aparelho psíquico, bem como o seu funcionamento, para entender os processos de repressão, de transferência e de sublimação do desejo. Para o psicanalista, o aparelho psíquico é composto de três instâncias que estão inter-relacionada: o ego, o superego e o id. ${ }^{9}$ O ego abrange a nossa consciência, portanto, as nossas ações “diurnas” e sociais. Em oposição ao ego, Freud aponta a existência do id ${ }^{10}$, instância na qual alojam-se nossos desejos

\footnotetext{
${ }^{8}$ Conforme Foucault (1990) em As Palavras e as Coisas.

${ }^{9}$ A tradução francesa optou por designar as instâncias como: eu, supereu, isso

${ }^{10}$ À guisa de curiosidade, o termo id não é correlato ao termo Inconsciente, tal como designado na primeira tópica do aparelho psíquico freudiano. Também não possui uma tradução satisfatória, ou melhor, um significado descritivo que dê conta de toda a significação que Freud atribuiu a este termo. No Vocabulário de Psicanálise (1997), por exemplo, o Id é traduzido por "Isso". Este termo é particularmente interessante porque o Inconsciente não é uma instância facilmente vista ou analisada pela racionalidade, ou seja, é tarefa árdua atribuir um significado ao Inconsciente. Nesse sentido de impossibilidade de acesso e descrição do Inconsciente, o termo "Isso" parece ser bastante plausível. Nessa linha, Foucault, no livro As Palavras e as Coisas (1990), afirma ser o Inconsciente da ordem do não saber..
}

(c) ETD - Educação Temática Digital, Campinas, v.8, n.esp., p.85-102, dez. 2006 - ISSN: 1676-2592. 
reprimidos e o superego ${ }^{11}$, instância intermediária entre o ego e o id, responsável pela avaliação e censuras das pulsões que emergentes do id. O superego é formado, basicamente, pela introjeção de valores morais ${ }^{12}$, religiosos e familiares, e pela manifestação diária desses valores. Dessa forma, as nossas ações são "vistoriadas" pela moral manifestada no superego. A civilização perpetua-se, como vimos na citação acima, graças à repressão dos desejos do homem, sendo que a instância repressora dos desejos é o superego. Dessa forma, a civilização prima pela efetiva ação repressora do superego que garantirá aos homens uma conduta de acordo com as necessidades da sociedade. As pulsões internas advindas do Id ficam latentes, produzindo uma grande quantidade de insatisfação. Como existe um desacordo primordial entre as exigências do Id e as exigências da civilização, o homem moderno está condenado a infelicidade. A falta, constituidora da existência humana por um lado, e as condições e exigências de perpetuação da coletividade por outro, tornam extremamente tensional a dimensão do Ego que se vê obrigado a responder as exigências tanto internas quanto externas.

Para Freud, a neurose é o nosso vizinho mais próximo, pois a frustração dos desejos é parte constitutiva da civilização. Ela se constitui no ovo de serpente que nossa civilização gesta cotidianamente:

Se a civilização impõe sacrifícios tão grandes, não apenas à sexualidade do homem, mas também à sua agressividade, podemos compreender melhor porque lhe é difícil ser feliz nessa civilização (...) O homem civilizado trocou uma parcela de suas possibilidades de felicidade por uma parcela de segurança. (FREUD, 1990, p. 137).

Dessa forma, a negação dos desejos ${ }^{13}$ é a pedra angular e o fundamento do processo civilizatório. Para Freud, assim como para Adorno, a satisfação do indivíduo perde sua

${ }^{11}$ Em $O$ ego e o Id, Freud afirmou ser o superego herdeiro do complexo de Édipo, ou seja, o superego se faz na repressão do desejo natural ao ser humano de cometer o incesto com a mãe e o parricídio. Cito: "Em idade muito precoce o menininho desenvolve uma catexia objetal pela mãe [...] o menino trata o pai identificando-se com este. Durante certo tempo, esses dois relacionamentos avançam lado a lado, até que os desejos sexuais do menino em relação à mãe se tornam mais intensos, e o pai é percebido como um obstáculo a eles; disso se origina o complexo de Édipo. Sua identificação com o pai assume uma coloração hostil e transforma-se num desejo de livrar-se dele, a fim de ocupar o seu lugar junto à mãe” (FREUD, 1990a, p. 46). É a partir desta repressão que o superego começara a controlar na realização dos nossos desejos.

${ }^{12}$ Ainda em $O$ Ego e o Id, Freud afirmou que o tipo de moral manifestada no superego é a moral kantiana (FREUD, 1990a, p. 49), assim no supergo temos a supremacia do dever agir kantiano.

${ }^{13}$ Em Totem e tabu (1990b), Freud caracterizou a gênese da civilização. Para ele, nossa civilização foi fundada sob a persistência de um tabu e a adoração de um totem. Numa horda primitiva, as fêmeas eram propriedade do macho mais forte que não as dividia com os outros machos mais fracos, causando a estes um grande desconforto. Para desfrutar sexualmente das fêmeas, os machos mais fracos uniram forças, matando e comendo a carne do macho líder. Uma vez que as fêmeas não tinham mais um único dono, os machos iriam lutar entre si pelas fêmeas, o que causaria a destruição da horda. Arrependidos pelo crime cometido contra o líder, os machos se uniram novamente e

(C) ETD - Educação Temática Digital, Campinas, v.8, n.esp., p.85-102, dez. 2006 - ISSN: 1676-2592. 
importância frente ao desenvolvimento da civilização. Assim, a infelicidade humana e seu malestar são plenamente justificados se, correlatos a essas frustrações, a civilização progredir na ciência, na tecnologia e na produção. No processo civilizatório, cito Freud,

de longe, o que mais importa é o objetivo de criar uma unidade a partir dos seres humanos individuais. É verdade que o objetivo da felicidade ainda se encontra aí, mas relegado ao segundo plano. Quase parece que a criação de uma grande comunidade humana seria mais bem sucedida se não se tivesse de se prestar atenção à felicidade do indivíduo. (FREUD, 1990, p. 165)

A constituição da civilização funda-se sobre as bases da renúncia das exigências individuais e da repressão das pulsões internas. A primazia do coletivo sobre o indivíduo permitiu ao ser humano aglutinar forças necessárias no processo de perpetuação da espécie. Porém, esse procedimento gestou também a alienação do sujeito ao coletivo, a sua diluição nas exigências coletivas e, como conseqüência, sua insatisfação. Nessa mesma perspectiva: “Mas, quanto mais o processo de auto-conservação é assegurado pela divisão burguesa do trabalho, tanto mais ele força a auto-alienação dos indivíduos, que têm que se formar no corpo e na alma segundo a aparelhagem técnica”. (ADORNO \& HORKHEIMER, 1985, p. 41)

O processo de desenvolvimento social emanado da racionalidade humana transformou-se num rolo compressor que esmaga a possibilidade de satisfação do homem. De criador da civilização, o homem moderno passou a ser criatura submissa e alienada à sua própria criação. Os ganhos de bem-estar propiciados pela civilização através das comunicações, transporte, medicina, ciência e tecnologia, funcionam como paliativos ao mal-estar do homem.

(...) não existe, então, nenhum ganho no prazer, nenhum aumento inequívoco no meu sentimento de felicidade, se posso, tantas vezes quantas me agrade, escutar a voz de um filho que está morando a milhares de quilômetros de distância [...]. Não significa nada que a medicina tenha conseguido não só reduzir enormemente a mortalidade infantil e o perigo de infecção para as mulheres no parto, como também, na verdade, prolongar consideravelmente a vida média do homem civilizado? [...] Aqui, porém, a voz da crítica pessimista se faz ouvir e nos adverte que a maioria dessas satisfações segue o modelo do 'prazer barato' louvado pela anedota: o prazer obtido ao se colocar a perna nua para fora das roupas de cama numa fria noite de inverno e recolhê-la novamente. (FREUD, 1990, p. 107).

Essa citação é particularmente profícua para estabelecermos a dinâmica de produção do homem alienado e administrado tal como demonstrado por Adorno e Horkheimer em A Dialética do Esclarecimento. Aparece nas duas obras citadas a crítica visceral ao processo de subjetivação

instituíram a adoração perpétua à memória do macho assassinado, transformando-o num Totem e instituíram um Tabu para evitar o conflito pelas fêmeas: nuca desfrutar sexualmente das fêmeas da mesma horda (incesto).

(C) ETD - Educação Temática Digital, Campinas, v.8, n.esp., p.85-102, dez. 2006 - ISSN: 1676-2592. 
do homem, ao processo de produção de um sujeito alienado de suas potencialidades. Tanto na sociologia, com a análise das relações de poder que a dimensão econômica e política exercem sobre o sujeito, produzindo homens alienados e destituídos de individualidade, quanto na dimensão do aparelho psíquico e da psicanálise com o diagnóstico das exigências impostas pelo princípio de realidade e pelo superego, encontramos o mesmo resultado: a produção do mal-estar e de sujeitos insatisfeitos e alienados.

É dessa forma, na leitura de Freud e de Adorno, que a civilização opera, ou seja, como a sociedade não pode propiciar aos homens felicidade, ela cria satisfações substitutivas, que se constituem em prazeres artificiais propiciados pelo consumo e pela facilidade da vida moderna. Na vida em civilização, o que resta aos homens é somente o contentamento com o tipo de prazer que a própria sociedade cria e oferece aos homens. Em síntese, da mesma forma que a civilização criou a massificação do consumo, ela criou, também, a massificação do prazer, isto é, o prazer individual deve estar submetido ao tipo de prazer proporcionado pela civilização. A indústria cultural compreendeu de forma magistral a condição do homem moderno. Incapaz de lidar com seu desejo e marcado pela falta, o homem moderno está condenado a buscar em instâncias diversas a produção de sua felicidade. A mesma civilização que impõe regras, valores, normas, que determina a forma de subsistência, que define um modelo de sociedade e que, portanto, produz o mal-estar na civilização cria a demanda que ela se propõe em satisfazer. A nossa civilização é bastante criativa no oferecimento de inúmeras formas de satisfação dessa falta que o homem não sabe lidar. Ela cria, de fato, formas substitutivas para apaziguar as exigências internas. É dessa forma que o trabalho parece como realização pessoal e o consumo como sinônimo de felicidade. Ausente de si mesmo, o homem moderno busca, infinitamente, aquilo, que ele não sabe o que é, mas que acredita irá diminuir a tensão interna. Emerge, enfim, na obra freudiana a constatação do trágico na existência humana, de um homem que não pode fugir de sua própria constituição de falante e faltante. Tragédia que se expressa na tensionalidade do indivíduo e da civilização, na tensionalidade das exigências internas e externas, na tencionalidade da falta e dos substitutos, na tensionalidade da saúde e da doença, na tensionalidade, enfim, da felicidade e do mal-estar. 


\section{REFERÊNCIAS}

ADORNO \& HORKHEIMER. Dialética do esclarecimento. Rio de Janeiro: Jorge Zahar, 1985.

ADORNO. Freud en la actualidad. Barcelona:Barril Editora, 1971.

. Dialéctica negativa. Madri: Taurus, 1975.

. Minima moralia. São Paulo: Ática, 1993.

DUBOIS, Claud Gilbert. O imaginário da Renascença. Brasília: UNB, 1995.

DESCARTES. O discurso do método. Coleção Os Pensadores. São Paulo: Abril Cultural, 1987.

. Meditações Metafísicas. Coleção Os Pensadores.São Paulo: Abril Cultural, 1987a.

ELLIOTT, Friedman. O desaparecimento de Deus. Rio de Janeiro: Imago, 1997.

FOUCAULT, Michel. As palavras e as coisas. São Paulo: Martins Fontes, 1990.

FROMM, Erich. Psicanálise da sociedade contemporânea. Rio de Janeiro: Zahar, 1983.

FREUD, S. “O mal-estar na civilização” In: Edição Standard Brasileira das Obras Psicológicas Completas. Volume XXI. Rio de Janeiro: Imago, 1990.

. “O ego e o id” In: Edição Standard Brasileira das Obras Psicológicas Completas. Volume XIX. Rio de Janeiro: Imago, 1990a.

“Totem e tabu” In: Edição Standard Brasileira das Obras Psicológicas

Completas. Volume XIII. Rio de Janeiro: Imago, 1990b.

LAPLANCHE \& PONTALIS. Vocabulário da psicanálise. São Paulo: Martins Fontes, 1997.

MARCUSE, Herbert. Eros e a civilização. Editora Guanabara, s/d.

SHATTUCK, Roger. Conhecimento proibido. São Paulo: Companhia das Letras, 1998.

MÁRCIO DANELON

Doutor em Educação pela Unicamp; Professor da Universidade Federal de Uberlândia-MG. Email: danelon@faced.ufu.br 